\title{
Spectrophotometric method for the determination of renal ouabain-sensitive $\mathrm{H}^{+}, \mathrm{K}^{+}$-ATPase activity
}

\author{
Jerzy Bełtowski ${ }^{\bowtie}$ and Grażyna Wójcicka \\ Department of Pathophysiology, Medical University, Lublin, Poland
}

Received: 20 February, 2002; revised: 28 April, 2002; accepted: 28 May, 2002

Key words: $\mathrm{Na}^{+}, \mathrm{K}^{+}$-ATPase, $\mathrm{H}^{+}, \mathrm{K}^{+}$-ATPase, ouabain, Sch 28080 , kidney, leptin

The aim of this work was to develop a method for renal $\mathrm{H}^{+}, \mathrm{K}^{+}$-ATPase measurement based on the previously used $\mathrm{Na}^{+}, \mathrm{K}^{+}$-ATPase assay (Beltowski et al.: $J$ Physiol Pharmacol.; 1998, 49: 625-37). ATPase activity was assessed by measuring the amount of inorganic phosphate liberated from ATP by isolated microsomal fraction. Both ouabain-sensitive and ouabain-resistant $\mathrm{K}^{+}$-stimulated and $\mathrm{Na}^{+}$-independent ATPase activity was detected in the renal cortex and medulla. These activities were blocked by $0.2 \mathrm{mM}$ imidazolpyridine derivative, Sch 28080 . The method for ouabainsensitive $\mathbf{H}^{+}, \mathrm{K}^{+}$-ATPase assay is characterized by good reproducibility, linearity and recovery. In contrast, the assay for ouabain-resistant $\mathrm{H}^{+}, \mathrm{K}^{+}$-ATPase was unsatisfactory, probably due to low activity of this enzyme. Ouabain-sensitive $\mathrm{H}^{+}, \mathrm{K}^{+}$-ATPase was stimulated by $\mathrm{K}^{+}$with $K_{\mathrm{m}}$ of $0.26 \pm 0.04 \mathrm{mM}$ and $0.69 \pm 0.11 \mathrm{mM}$ in cortex and medulla, respectively, and was inhibited by ouabain $\left(K_{\mathrm{i}}\right.$ of $2.9 \pm 0.3 \mu \mathrm{M}$ in the renal cortex and $1.9 \pm 0.4 \mu \mathrm{M}$ in the renal medulla) and by $\operatorname{Sch} 28080\left(K_{\mathrm{i}}\right.$ of $1.8 \pm 0.5 \mu \mathrm{M}$ and $2.5 \pm$ $0.9 \mu \mathrm{M}$ in cortex and medulla, respectively). We found that ouabain-sensitive $\mathrm{H}^{+}, \mathrm{K}^{+}$-ATPase accounted for about $12 \%$ of total ouabain-sensitive activity in the $\mathrm{Na}^{+}, \mathrm{K}^{+}$-ATPase assay. Therefore, we suggest to use $\mathrm{Sch} 28080$ during $\mathrm{Na}^{+}, \mathrm{K}^{+}$-ATPase measurement to block $\mathrm{H}^{+}, \mathrm{K}^{+}$-ATPase and improve the assay specificity. Leptin administered intraperitoneally $(1 \mathrm{mg} / \mathrm{kg})$ decreased renal medullary $\mathrm{Na}^{+}, \mathrm{K}^{+}$-ATPase activity by $32.1 \%$ at $1 \mathrm{~h}$ after injection but had no effect on $\mathrm{H}^{+}, \mathrm{K}^{+}$-ATPase activity suggesting that the two renal ouabain-sensitive ATPases are separately regulated.

Apart from their important role in sodium homeostasis, the kidneys have also to maintain potassium balance by adjusting its urinary excretion to variable alimentary intake.
The mechanisms regulating $\mathrm{K}^{+}$homeostasis are not completely understood (Rabinowitz, 1996). Renal potassium handling consists of glomerular filtration, tubular reabsorption

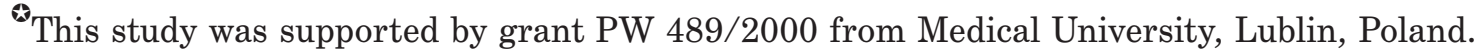

${ }^{\square}$ Address for correspondence: Jerzy Bełtowski, Department of Pathophysiology, Medical University, K. Jaczewskiego 8, 20-090 Lublin, Poland, tel: (48 81) 74258 35-37; fax: (48 81) 532 8903; e-mail: patfiz@asklepios.am.lublin.pl
} 
and tubular secretion (Giebisch \& Wang, 1996; Giebisch, 1998; Muto, 2001). Traditionally, it has been believed that only $\mathrm{K}^{+}$secretion in the collecting duct is involved in the regulation of potassium excretion. Potassium reabsorption, occurring predominantly in more proximal nephron segments, was long considered as a passive process driven by sodium and water transport and not independently regulated. This point of view has been revised after the identification in renal tubules of $\mathrm{H}^{+}, \mathrm{K}^{+}$-ATPase which suggested the existence of specific $\mathrm{K}^{+}$reabsorbing mechanisms (Doucet \& Marsy, 1987; Garg \& Narang, 1988). $\mathrm{H}^{+}, \mathrm{K}^{+}$-ATPase, located in the apical membranes of tubular cells, actively transports $\mathrm{K}^{+}$from the tubular lumen to the cell and protons in the opposite direction, and thus is involved in potassium reabsorption and urine acidification (Wingo \& Smolka, 1995; Silver \& Soleimani, 1999). Renal $\mathrm{H}^{+}, \mathrm{K}^{+}$-ATPase exists in at least three different isoforms: type I localized in intercalated cells of the collecting duct, type II expressed in proximal tubules and thick ascending limbs of Henle's loop, and type III, which is not expressed under physiological conditions but appears in principal cells of the collecting ducts in potassium-depleted animals. All these isoforms are inhibited by 2-methyl-8-(phenylmethoxy)imidazol(1,2- $\alpha$ ) pyridine-3-acetonitrile (Sch 28080) (YounesIbrahim et al., 1995; Buffin-Meyer et al., 1997; Doucet, 1997; Laroche-Joubert et al., 2000).

For over 40 years ouabain was considered to be a specific inhibitor of $\mathrm{Na}^{+}, \mathrm{K}^{+}$-ATPase. However, recent studies indicate that ouabain can also inhibit the activity of type II and type III $\mathrm{H}^{+}, \mathrm{K}^{+}$-ATPases (Younes-Ibrahim et al., 1995; Buffin-Meyer et al., 1997). These findings raised the question of specificity of the currently used methods of $\mathrm{Na}^{+}, \mathrm{K}^{+}$-ATPase determination. Most, if not all, of these methods, including that used by us in our previous studies (Bełtowski et al., 1998a, 1998b), define $\mathrm{Na}^{+}, \mathrm{K}^{+}$-ATPase as ouabain-inhibitable activ- ity. Ouabain sensitivity of some $\mathrm{H}^{+}, \mathrm{K}^{+}$ATPases suggests that " $\mathrm{Na}^{+}, \mathrm{K}^{+}$-ATPase" measured in this manner may in fact contain, apart from true $\mathrm{Na}^{+}, \mathrm{K}^{+}$-ATPase, also ouabainsensitive $\mathrm{H}^{+}, \mathrm{K}^{+}$-ATPase activity.

The aim of the present study was to develop a method for $\mathrm{H}^{+}, \mathrm{K}^{+}$-ATPase determination based on the protocol previously used by us to determine renal $\mathrm{Na}^{+}, \mathrm{K}^{+}$-ATPase activity. We have also studied what part of ouabain-sensitive " $\mathrm{Na}^{+}, \mathrm{K}^{+}$-ATPase" measured by this method is in fact accounted for by ouabainsensitive $\mathrm{H}^{+}, \mathrm{K}^{+}$-ATPase. Finally, to evaluate whether $\mathrm{Na}^{+}, \mathrm{K}^{+}$-ATPase and $\mathrm{H}^{+}, \mathrm{K}^{+}$-ATPase are independently regulated, we investigated the effect of leptin, previously shown to inhibit $\mathrm{Na}^{+}, \mathrm{K}^{+}$-ATPase (Bełtowski et al., 1999; Sweeney et al., 2000), on both renal ouabainsensitive " $\mathrm{X}^{+}, \mathrm{K}^{+}$-ATPases".

\section{MATERIALS AND METHODS}

Animals and tissue preparation. All studies were performed on adult male Wistar rats weighing 200-250 g. The animals were kept at $20 \pm 2^{\circ} \mathrm{C}$ and had free access to food and tap water before the experiment. To maintain normokalemia, the chow contained 150 $\mathrm{mmol} / \mathrm{kg}$ potassium. The study protocol was reviewed and approved by the Animal Care and Use Committee of the Medical University in Lublin.

The rats were anaesthetized with pentobarbital (50 mg/kg i.p.). Then, the abdominal cavity was opened and the aorta was cannulated distally to the renal arteries. The blood for the assay of electrolytes was collected into EDTA-containing tubes and centrifuged for $5 \mathrm{~min}$ at 3000 r.p.m. at $4^{\circ} \mathrm{C}$. Plasma was separated, frozen and stored at $-25^{\circ} \mathrm{C}$. Immediately after blood withdrawal, the abdominal aorta was ligated proximally to the renal arteries and $5 \mathrm{ml}$ of physiological saline was infused slowly through a cannula to remove erythrocytes from the kidney. After this procedure the kidneys became pale and con- 
tained virtually no erythrocytes, as confirmed by light microscopy.

For the ATPase activity assay the microsomal fraction of the renal cortex and medulla was isolated by the method of Jörgensen (1974) with slight modification. The kidneys were removed and stored in ice-cold solution containing $0.25 \mathrm{M}$ sucrose and $0.03 \mathrm{M}$ histidine ( $\mathrm{pH}$ 7.2). The medulla and cortex were separated by dissection and homogenized in sucrose-histidine solution (10 $\mathrm{ml} / \mathrm{g}$ tissue) using a glass homogenizer. The homogenate was centrifuged at $8000 \times g$ for $20 \mathrm{~min}$ at $4^{\circ} \mathrm{C}$. The sediment was resuspended in $6 \mathrm{ml}$ of sucrose-histidine solution and centrifuged again. The combined supernatants were centrifuged at $50000 \times \mathbf{g}$ for $30 \mathrm{~min}$ at $4^{\circ} \mathrm{C}$. The pellet (microsomal fraction) was resuspended in $4 \mathrm{ml}$ of sucrose-histidine solution and stored at $-25^{\circ} \mathrm{C}$. The enzyme assay was completed within $24 \mathrm{~h}$.

$\boldsymbol{H}^{+}, \boldsymbol{K}^{+}$-ATPase assay. The sample was thawed and then diluted to yield $500 \mu \mathrm{g}$ protein $/ \mathrm{ml}$ solution. ATPase activity was assayed by measuring the amount of inorganic phosphate $\left(\mathrm{P}_{\mathrm{i}}\right)$ liberated from ATP during incubation of the microsomal fraction in the presence of appropriate activators. $\mathrm{H}^{+}, \mathrm{K}^{+}$-ATPase was measured as $\mathrm{K}^{+}$-stimulated ATP hydrolysis. The assay medium $(1 \mathrm{ml})$ contained $5 \mathrm{mM}$ $\mathrm{KCl}, 10 \mathrm{mM} \mathrm{MgCl}_{2}, 1 \mathrm{mM}$ EGTA, $5 \mathrm{mM}$ Tris/ATP and $25 \mathrm{mM}$ Tris/HCl (pH 7.4), as described by Buffin-Meyer et al. (1997). This solution differs from that used by us previously for $\mathrm{Na}^{+}, \mathrm{K}^{+}$-ATPase assay in that: 1) it does not contain $\mathrm{NaCl}$ and contains Tris salt of ATP instead of sodium salt to exclude $\mathrm{Na}^{+}, \mathrm{K}^{+}$-ATPase activity; 2) it contains EGTA to block $\mathrm{Ca}^{2+}$-ATPases which could generate high background activity. For the assay of basal, $\mathrm{K}^{+}$-independent $\mathrm{Mg}^{2+}$-ATPase, $\mathrm{KCl}$ was omitted and Sch 28080 (0.2 mM) was added to block any residual $\mathrm{H}^{+}, \mathrm{K}^{+}$-ATPase activity. At this concentration Sch 28080 completely inhibits $\mathrm{H}^{+}, \mathrm{K}^{+}$-ATPases while it has no effect on $\mathrm{Na}^{+}, \mathrm{K}^{+}$-ATPase (Younes-Ibrahim et al., 1995). The third sample was assayed in the presence of $5 \mathrm{mM} \mathrm{KCl}$ and $1 \mathrm{mM}$ ouabain to block ouabain-sensitive $\mathrm{H}^{+}, \mathrm{K}^{+}$-ATPase. The latter was defined as the difference in activity between the samples assayed in the absence and the presence of ouabain, both containing $5 \mathrm{mM} \mathrm{KCl}$. Ouabain-resistant $\mathrm{H}^{+}, \mathrm{K}^{+}$-ATPase was calculated as the difference between total and ouabain-sensitive $\mathrm{H}^{+}, \mathrm{K}^{+}$-ATPase activity.

For enzyme assay, $50 \mu \mathrm{g}(0.1 \mathrm{ml})$ of microsomal protein was added to the incubation medium together with appropriate inhibitors and the sample was incubated for $10 \mathrm{~min}$ at $37^{\circ} \mathrm{C}$. Then $5 \mathrm{mM}$ Tris/ATP was added. Since we expected lower activity of $\mathrm{H}^{+}, \mathrm{K}^{+}$-ATPase than of $\mathrm{Na}^{+}, \mathrm{K}^{+}$-ATPase, in preliminary experiments we prolonged the time of incubation with substrate from 15 to $30 \mathrm{~min}$. The reaction was terminated by adding $0.35 \mathrm{ml}$ of ice-cold $1 \mathrm{M}$ $\mathrm{HClO}_{4}$, and inorganic phosphate was measured by the spectrophotometric method of Hurst (1964). According to this method, 0.2 $\mathrm{ml}$ of the incubation medium was diluted with water to $3 \mathrm{ml}$ and $0.6 \mathrm{ml}$ of sodium molybdate reagent $\left(0.31 \mathrm{M} \mathrm{Na}_{2} \mathrm{MoO}_{4}\right.$ in $\left.1.5 \mathrm{M} \mathrm{H}_{2} \mathrm{SO}_{4}\right)$ was added to form a phosphomolybdate complex which was subsequently reduced to molybdenum blue by adding $0.6 \mathrm{ml}$ of stannous chloride-hydrazine sulphate reagent containing $\mathrm{SnCl}_{2}(1.3 \mu \mathrm{M})$, hydrazine sulphate (23 $\mu \mathrm{M})$ and $\mathrm{H}_{2} \mathrm{SO}_{4}(0.5 \mu \mathrm{M})$. Absorbance was read after $20 \mathrm{~min}$ at $700 \mathrm{~nm}$. To correct for any spontaneous ATP hydrolysis, the absorbance of a blank sample, prepared as described above but without microsomal protein, was subtracted from the absorbance of the test sample. ATPase activity was expressed in $\mu \mathrm{mol}$ of inorganic phosphate liberated by $1 \mathrm{mg}$ of microsomal protein during $1 \mathrm{~h}$ ( $\mu \mathrm{mol} / \mathrm{h}$ per mg protein). Each sample was assayed in triplicate and the mean was used for further calculations. The amount of phosphate was read from the standard curve prepared using known concentrations of $\mathrm{KH}_{2} \mathrm{PO}_{4}$.

$\mathrm{Na}^{+}, \boldsymbol{K}^{+}$-ATPase assay. $\mathrm{Na}^{+}, \mathrm{K}^{+}$-ATPase activity was measured as described above, in the incubation solution containing: $100 \mathrm{mM} \mathrm{NaCl}$, 
$20 \mathrm{mM} \mathrm{KCl}, 4 \mathrm{mM} \mathrm{MgCl}_{2}, 1 \mathrm{mM}$ EGTA, 40 $\mathrm{mM}$ Tris/ $\mathrm{HCl}(\mathrm{pH} 7.4)$ and $3 \mathrm{mM} \mathrm{Na} \mathrm{N}_{2}$ ATP. The incubation time with substrate was 15 min. Four samples from each homogenate were assayed simultaneously: 1) without inhibitors, 2) with $2 \mathrm{mM}$ ouabain, 3) with 0.2 $\mathrm{mM}$ Sch 28080 and, 4) with both ouabain and Sch 28080 . The difference between samples 1 and 2 was used as a measure of $\mathrm{Na}^{+}, \mathrm{K}^{+}$ATPase in our previous studies; samples 3 and 4 were assayed to eliminate the possible contribution of ouabain-sensitive $\mathrm{H}^{+}, \mathrm{K}^{+}$ATPase; thus the difference between sample 3 and 4 corresponds to the true $\mathrm{Na}^{+}, \mathrm{K}^{+}$-ATPase activity.

Leptin administration. The effect of leptin on renal $\mathrm{Na}^{+}, \mathrm{K}^{+}$-ATPase and $\mathrm{H}^{+}, \mathrm{K}^{+}$-ATPase activity was studied in additional 2 groups of rats. One group received leptin ( $1 \mathrm{mg} / \mathrm{kg}$ i.p.) and the control group the same volume $(0.5$ $\mathrm{ml}$ ) of vehicle (phosphate buffered saline, $\mathrm{pH}$ 7.0). After $1 \mathrm{~h}$ the animals were anaesthetized and the kidneys were removed for ATPases assay. At that time leptin had the maximal inhibitory effect on renal medullary $\mathrm{Na}^{+}, \mathrm{K}^{+}$ATPase (Bełtowski et al., 1999). In these studies we assayed only ouabain-sensitive $\mathrm{H}^{+}, \mathrm{K}^{+}$-ATPase and $\mathrm{Na}^{+}, \mathrm{K}^{+}$-ATPase, the latter both in the presence and in the absence of Sch 28080.

Other assays. Protein concentration in the microsomal fraction was assayed by the method of Lowry et al. (1951) using bovine serum albumin as a standard. Plasma potassium concentration was measured by flame photometry. In addition to renal tissue, $\mathrm{Na}^{+}, \mathrm{K}^{+}$-ATPase and ouabain-sensitive $\mathrm{H}^{+}, \mathrm{K}^{+}$ATPase activity was assayed in brain and heart obtained from 5 control animals.

Reagents. ATP, ouabain, L-histidine, Tris, and EGTA were obtained from Sigma-Aldrich. Sch 28080 was kindly provided by Schering-Plough Research Institute (Kenilworth, NJ, U.S.A.). Sch 28080 was dissolved in methanol to form a $100 \mathrm{mM}$ stock solution; $2 \mu \mathrm{l}$ of this solution was added to $1 \mathrm{ml}$ of the incubation mixture to yield a concentration of
$200 \mu$ M. Ouabain was dissolved in ethanol and then diluted with water. The final concentrations of methanol and ethanol in the incubation mixture were $0.2 \%$ and $1 \%$, respectively. At these concentrations the solvents alone had no effect on renal ATPases, as observed in preliminary experiments. Recombinant human leptin was obtained from R\&D Systems Ltd. (U.K.). As recommended by the manufacturer, leptin was first dissolved in $1 \mathrm{ml}$ of deionized water and then diluted with phosphate buffered saline ( $\mathrm{pH}$ 7.2) to a final concentration of $0.4 \mathrm{mg} / \mathrm{ml}$, then frozen and stored at $-25^{\circ} \mathrm{C}$. Other reagents were of the highest research grade available.

Kinetic calculations. The relationship between potassium concentration and $\mathrm{H}^{+}, \mathrm{K}^{+}$-ATPase activity was fitted to the following equation:

$V=V_{\max }\left[\mathrm{K}^{+}\right] /\left(K_{\mathrm{m}}+\left[\mathrm{K}^{+}\right]\right)$

where $V$ is the $\mathrm{H}^{+}, \mathrm{K}^{+}$-ATPase activity measured at a given potassium concentration $\left[\mathrm{K}^{+}\right], V_{\max }$ is the maximal activity and $K_{\mathrm{m}}$ is the apparent Michaelis constant. The inhibition of $\mathrm{H}^{+}, \mathrm{K}^{+}$-ATPase by ouabain and Sch 28080 was analyzed according to the following formula:

$V=V_{\max } /\left(1+[\mathrm{I}] / K_{\mathrm{i}}\right)$

where $V$ is the $\mathrm{H}^{+}, \mathrm{K}^{+}$-ATPase activity measured at a given concentration of inhibitor [I], $V_{\max }$ is the maximal activity and $K_{\mathrm{i}}$ is the inhibition constant. The kinetic parameters were calculated by nonlinear least squares regression separately for each animal.

To study the reproducibility of the $\mathrm{H}^{+}, \mathrm{K}^{+}$ATPase assay, samples from 5 different animals were studied in 5 replicates simultaneously to calculate the intra-assay coefficient of variation (CV), as well as on 5 different days to calculate the inter-assay CV. The recovery of inorganic phosphate was studied by adding known amounts (64, 320 or $640 \mathrm{nmol}$, 
each in triplicate) of $\mathrm{KH}_{2} \mathrm{PO}_{4}$ to the incubation mixture during the enzyme assay. The sensitivity of the assay was determined as 2 standard deviations of 10 independently performed blank samples.

Statistics. Data are presented as mean \pm S.E.M. from 8 experiments in each group. Statistical significance was evaluated by singlemeasures or repeated-measures analysis of variance (ANOVA) followed by Duncan's multiple range test for comparisons of different means; $P<0.05$ was considered significant.

\section{RESULTS}

\section{$\mathrm{K}^{+}$-stimulated ATPase in renal tissue and its sensitivity to inhibitors}

Plasma $\mathrm{K}^{+}$concentration in the experimental animals was $4.36 \pm 0.21 \mathrm{mM}$, confirming their normokalemic state. Figure 1 demonstrates ATPase activity measured in different incubation media. $\mathrm{K}^{+}$markedly stimulated the ATP hydrolyzing activity both in the renal cortex and medulla. The difference between $\mathrm{K}^{+}$-stimulated and basal ATPase activity can be accounted for by $\mathrm{H}^{+}, \mathrm{K}^{+}$-ATPase. The $\mathrm{K}^{+}$-stimulated activity was partially inhibited by $1 \mathrm{mM}$ ouabain. However, the activity assayed in the presence of ouabain was still higher than in the sample without $\mathrm{K}^{+}$. These data suggest that $\mathrm{K}^{+}$-stimulated ATPase activity consists of two fractions, one of them being ouabain-sensitive and the other ouabain-resistant. In further studies the difference between $\mathrm{K}^{+}$-stimulated ATPase assayed in the absence and in the presence of ouabain was used as a measure of ouabain-sensitive $\mathrm{H}^{+}, \mathrm{K}^{+}$-ATPase, whereas the difference between activity assayed in the sample containing $\mathrm{K}^{+}$and ouabain and the activity assayed without $\mathrm{K}^{+}$ but with Sch 28080 - as a measure of ouabainresistant $\mathrm{H}^{+}, \mathrm{K}^{+}$-ATPase (Fig. 1).

The activity measured in the presence of Sch 28080 and $\mathrm{K}^{+}$was not significantly different from basal $\mathrm{K}^{+}$-independent activity measured

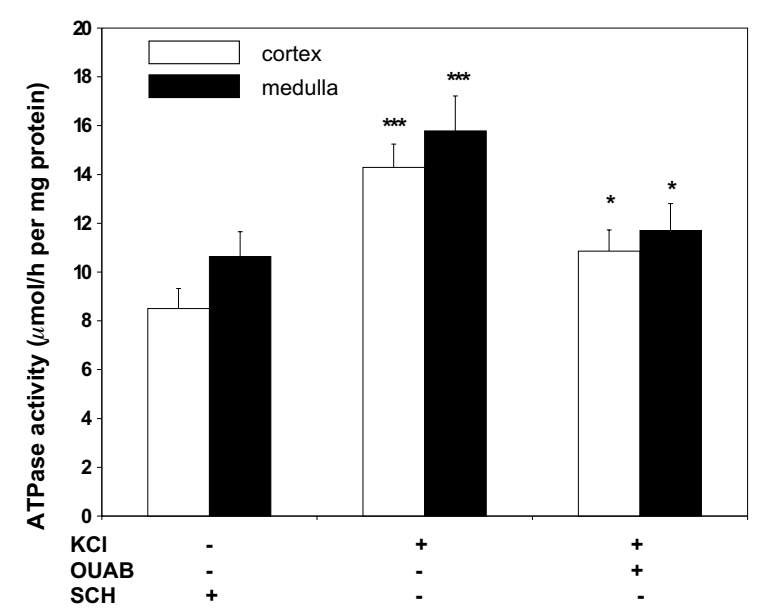

Figure 1. ATPase hydrolyzing activity in isolated microsomal fraction isolated from renal cortex and medulla measured in the presence of activator $\left(5 \mathrm{mM} \mathrm{K}^{+}\right.$) and/or inhibitors ( $1 \mathrm{mM}$ ouabain or $0.2 \mathrm{mM}$ Sch 28080).

Enzyme activity is expressed in $\mu \mathrm{mol}$ of inorganic phosphate liberated by $1 \mathrm{mg}$ of microsomal protein during $1 \mathrm{~h}\left(\mu \mathrm{mol} \mathrm{P}_{\mathrm{i}} / \mathrm{h}\right.$ per mg protein); $\mathrm{n}=8$ rats in each group. ${ }^{*} P<0.05$, ${ }^{* * *} P<0.001$, compared to control (basal activity measured in the absence of $\mathrm{K}^{+}$but in the presence of Sch 28080) by repeated-measures ANOVA.

with Sch 28080 (not shown). Thus, $\mathrm{K}^{+}$was not able to activate ATPase in the presence of Sch 28080, which confirms that the latter compound completely inhibited $\mathrm{H}^{+}, \mathrm{K}^{+}$-ATPase. In addition, ouabain had no effect on ATPase assayed in the presence of $\mathrm{K}^{+}$and Sch 28080 (not shown) indicating that no ouabain-sensitive but Sch 28080-resistant ATPases were present in the preparation. Moreover, $\mathrm{K}^{+}$ failed to stimulate ATPase activity in the presence of $10^{-5} \mathrm{M}$ vanadate, which is an inhibitor of all P-type ATPases (Feraille \& Doucet, 2001); this confirms that $\mathrm{K}^{+}$-stimulated ATPase belongs to this superfamily. Furthermore, neither ouabain nor Sch 28080 had any significant effect on ATPase activity assayed in the absence of $\mathrm{K}^{+}$, indicating that no ouabain-sensitive or Sch 28080-sensitive but $\mathrm{K}^{+}$-independent ATPases are present. This is an important finding, confirming the specificity of Sch 28080 toward $\mathrm{H}^{+}, \mathrm{K}^{+}$-ATPase in this assay. 
To test the specificity of $\mathrm{H}^{+}, \mathrm{K}^{+}$-ATPase activation by $\mathrm{K}^{+}$, we performed additional experiments in which $\mathrm{KCl}$ in the incubation solution was replaced by $5 \mathrm{mM} \mathrm{NaCl}$. Although $\mathrm{Na}^{+}$ tended to stimulate ATPase activity (in the absence of $\mathrm{K}^{+}$), this effect was not significant. However, this slight stimulation of ATPase by $\mathrm{Na}^{+}$is noteworthy because it was observed reproducibly both in cortex and medulla, and appeared also in samples to which either ouabain or Sch 28080 was added (not shown). Due to insensitivity to the respective inhibitors, ATPase activity assayed in the presence of $\mathrm{Na}^{+}$could not be accounted for by either $\mathrm{Na}^{+}, \mathrm{K}^{+}$-ATPase or $\mathrm{H}^{+}, \mathrm{K}^{+}$-ATPase. We suggest that this $\mathrm{Na}^{+}$-stimulated ATPase activity could result from ouabain-insensitive $\mathrm{Na}^{+}$-stimulated ATPase found in proximal tubules (Caruso-Neves et al., 2000). Further studies with higher $\mathrm{Na}^{+}$concentration are needed to clarify this issue.

Figure 2 presents the calculated ouabainsensitive and ouabain-resistant $\mathrm{H}^{+}, \mathrm{K}^{+}$-ATPase activities. Ouabain-sensitive $\mathrm{H}^{+}, \mathrm{K}^{+}$-ATPase activity was by $13.3 \%$ higher in the renal medulla than in the renal cortex. In contrast, ouabain-resistant fraction was by $104.7 \%$ higher in cortex than in medulla. Ouabain-resistant $\mathrm{H}^{+}, \mathrm{K}^{+}$-ATPase activity was markedly

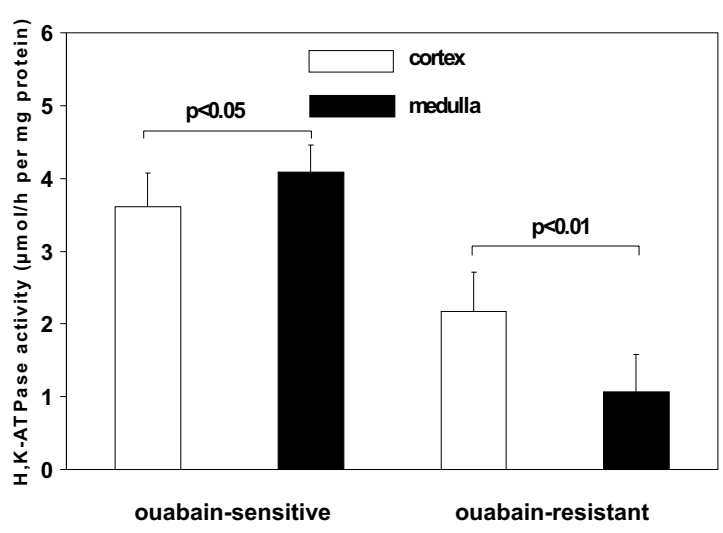

Figure 2. Ouabain-sensitive and ouabain-resistant $\mathrm{H}^{+}, \mathbf{K}^{+}$-ATPase activity in the renal cortex and medulla.

Values have been calculated from the data presented in Fig. 1 (see Methods). Statistical significance was evaluated by repeated-measures ANOVA. lower than that of the ouabain-sensitive fraction both in cortex $(-39.9 \%)$ and in medulla $(-74.1 \%)$. In contrast to renal tissue, no $\mathrm{K}^{+}$-stimulated ATPase activity was detected in brain or heart homogenates, although oubainsensitive $\mathrm{Na}^{+}, \mathrm{K}^{+}$-ATPase activity was observed in these organs (not shown).

\section{Characteristics of $\mathrm{H}^{+}, \mathrm{K}^{+}$-ATPase assay}

To verify the method for $\mathrm{H}^{+}, \mathrm{K}^{+}$-ATPase assay, we determined the relationship between incubation time and the respective activities. We assayed enzyme activity after 10, 20, 30, 40 and 50-min of incubation. Within this range the linearity of the relationship between ouabain-sensitive $\mathrm{H}^{+}, \mathrm{K}^{+}$-ATPase and incubation time was excellent (cortex: $\mathrm{r}^{2}=0.98$, $P<0.001$; medulla: $\left.\mathrm{r}^{2}=0.99, P<0.001\right)$. In contrast, ouabain-resistant $\mathrm{H}^{+}, \mathrm{K}^{+}$-ATPase demonstrated poor linearity (cortex: $\mathrm{r}^{2}=0.52$, $P=0.167$; medulla: $\left.\mathrm{r}^{2}=0.55, P=0.154\right)$. To investigate the effect of the amount of microsomal protein, we added $10,30,50,70$ or 90 $\mu \mathrm{g}$ protein to the incubation mixture and incubated it for 30-min. Again, the linearity was excellent for ouabain-sensitive $\mathrm{H}^{+}, \mathrm{K}^{+}$- ATPase (cortex: $\mathrm{r}^{2}=0.98, P<0.001$; medulla: $\mathrm{r}^{2}=$ $0.97, P<0.001$ ) and poor for the ouabain- resistant enzyme (cortex: $\mathrm{r}^{2}=0.728, P=0.142$; medulla: $\left.\mathrm{r}^{2}=0.74, P=0.183\right)$. Thus, the conditions used by us in preliminary studies $(50 \mu \mathrm{g}$ of protein and 30-min incubation time) are well within the linearity range only for ouabain-sensitive $\mathrm{H}^{+}, \mathrm{K}^{+}$-ATPase.

The reproducibility of $\mathrm{H}^{+}, \mathrm{K}^{+}$-ATPase assay was good for the ouabain-sensitive enzyme and poor for the ouabain-resistant fraction (Table 1). The recovery of inorganic phosphate was good for two lower doses (Table 1) and distinctly lower only for its highest dose. It should be noted, however, that the latter dose exceeded about tenfold the amount of $\mathrm{P}_{\mathrm{i}}$ generated by ouabain-sensitive $\mathrm{K}^{+}$-ATPase during the assay. Thus, the recovery was satisfactory within the range of phosphate liberated by ouabain-sensitive $\mathrm{H}^{+}, \mathrm{K}^{+}$-ATPase. The 
Table 1. Reproducibility of $\mathbf{H}^{+}, \mathbf{K}^{+}$-ATPase assay (coefficients of variation, $\mathrm{CV}$ ) and recovery of inorganic phosphate.

For details, see Methods.

\begin{tabular}{lll}
\hline & \multicolumn{2}{l}{ ouabain-sensitive $\mathrm{H}^{+}, \mathrm{K}^{+}$-ATPase } \\
\cline { 2 - 3 } & cortex & medulla \\
\hline intra-assay CV & $1.99 \%$ & $2.97 \%$ \\
inter-assay CV & $3.12 \%$ & $5.14 \%$ \\
\hline & ouabain-resistant $\mathrm{H}^{+}, \mathrm{K}^{+}$-ATPase \\
\hline intra-assay CV & $11.5 \%$ & $12.8 \%$ \\
inter-assay CV & $29.4 \%$ & $25.9 \%$ \\
\hline amount of $\mathrm{P}_{\mathrm{i}}$ added & recovery & $107.0 \pm 2.8 \%$ \\
\hline 64 nmol & $112.5 \pm 3.4 \%$ & $94.2 \pm 1.4 \%$ \\
320 nmol & $88.3 \pm 1.2 \%$ & $81.4 \pm 1.1 \%$ \\
640 nmol & $77.9 \pm 0.9 \%$ & \\
\hline
\end{tabular}

detection limit of the assay was $0.51 \mu \mathrm{mol} / \mathrm{h}$ per mg protein, i.e. it was about sevenfold lower than the mean ouabain-sensitive $\mathrm{H}^{+}, \mathrm{K}^{+}$ATPase activity in control rats.

Taken together, these data indicate that the described method for ouabain-sensitive $\mathrm{H}^{+}, \mathrm{K}^{+}$-ATPase assay is reliable, as evidenced by good linearity, reproducibility, recovery and activity/sensitivity ratio. In contrast, the method is unsatisfactory for ouabain-resistant $\mathrm{H}^{+}, \mathrm{K}^{+}$-ATPase assay. The attempts to improve its parameters by changing incubation time and/or the amount of protein were unsuccessful. Therefore, further studies were performed only on ouabain-sensitive $\mathrm{H}^{+}, \mathrm{K}^{+}$- ATPase.

\section{Kinetic analysis of ouabain-sensitive $\mathbf{H}^{+}, \mathbf{K}^{+}$-ATPase}

As demonstrated on Fig. 3, potassium activated ouabain-sensitive $\mathrm{H}^{+}, \mathrm{K}^{+}$-ATPase in a concentration-dependent manner with $K_{\mathrm{m}}$ of $0.26 \pm 0.04 \mathrm{mM}$ and $0.69 \pm 0.11 \mathrm{mM}$ in cortex and medulla, respectively. The enzyme was inhibited by ouabain with $K_{\mathrm{i}}$ of $2.9 \pm 0.3 \mu \mathrm{M}$ in the renal cortex and $1.9 \pm 0.4 \mu \mathrm{M}$ in the renal

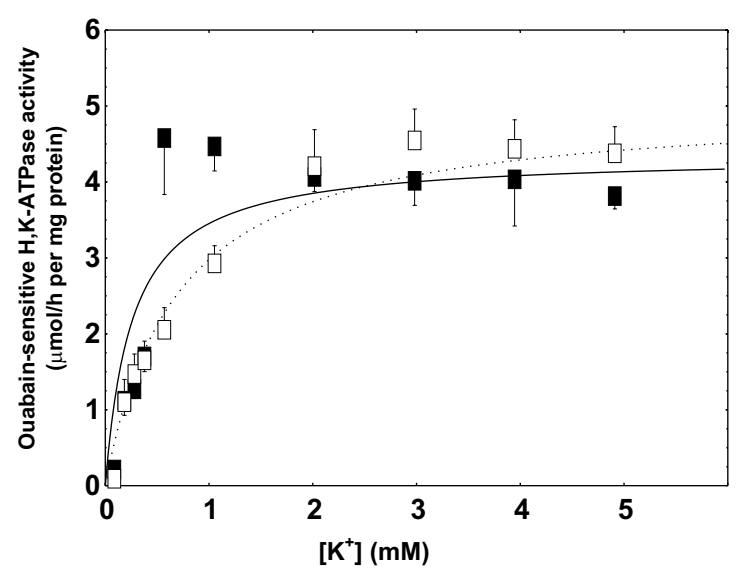

Figure 3. The effect of potassium concentration on ouabain-sensitive $\mathrm{H}^{+}, \mathrm{K}^{+}$-ATPase activity in the renal cortex (black squares and continuous line) and medulla (white squares and broken line).

On the vertical axis is indicated the difference between the activity assayed in the absence and in the presence of $1 \mathrm{mM}$ ouabain. Potassium was added to both samples at the indicated concentrations. Points represent mean \pm S.E.M. from 8 experiments and curves are the best fits of means to Eqn. 1 (see Methods).

medulla (Fig. 4). The estimated $K_{\mathrm{i}}$ for Sch 28080 was $1.8 \pm 0.5 \mu \mathrm{M}$ and $2.5 \pm 0.9 \mu \mathrm{M}$ for cortex and medulla, respectively (Fig. 5). 


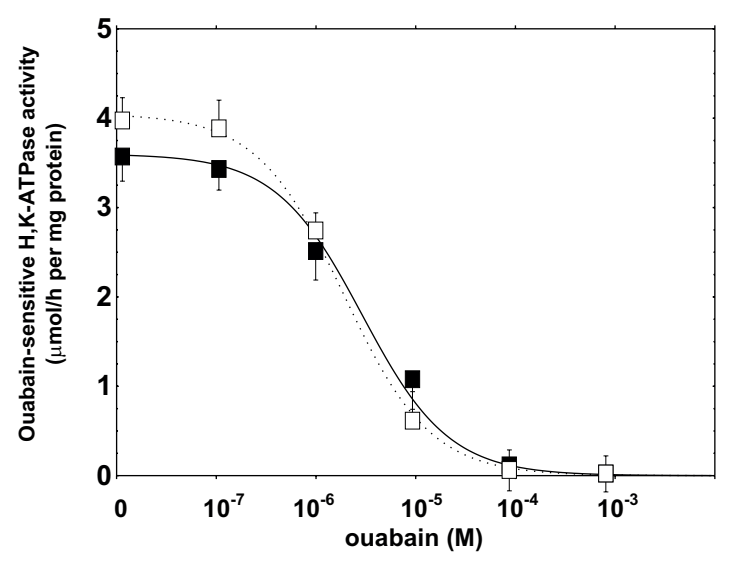

Figure 4. The effect of ouabain on renal ouabainsensitive $\mathrm{H}^{+}, \mathrm{K}^{+}$-ATPase activity in the renal cortex (black squares and continuous line) and medulla (white squares and broken line).

Vertical axis represents the difference between ATPase activity assayed in the presence of different concentrations of ouabain and in the presence of $1 \mathrm{mM}$ ouabain (each sample contained $5 \mathrm{mM} \mathrm{K}^{+}$). Points represent mean \pm S.E.M. from 8 experiments and curves are the best fits of means to Eqn. 2 (see Methods).

\section{Ouabain-sensitive $\mathbf{H}^{+}, \mathbf{K}^{+}$-ATPase interferes with $\mathrm{Na}^{+}, \mathrm{K}^{+}$-ATPase assay}

The existence of ouabain-sensitive $\mathrm{H}^{+}, \mathrm{K}^{+}$ATPase suggests that this enzyme is active during $\mathrm{Na}^{+}, \mathrm{K}^{+}$-ATPase assay and falsely elevates the measured activity. We wanted to establish what part of " $\mathrm{Na}^{+}, \mathrm{K}^{+}$-ATPase" measured as ouabain-sensitive activity was in fact accounted for by ouabain-sensitive $\mathrm{H}^{+}, \mathrm{K}^{+}$ATPase. For this purpose we assayed $\mathrm{Na}^{+}, \mathrm{K}^{+}$ATPase in the absence as well as in the presence of $0.2 \mathrm{mM}$ Sch 28080 . At this concentration Sch 28080 has no effect on renal $\mathrm{Na}^{+}, \mathrm{K}^{+}$ATPase activity (Codina et al., 2000). The enzyme activity assayed in the presence of Sch 28080 was by $12.6 \%(P<0.01)$ and $12.0 \%(P<$ 0.01 ) lower in the renal cortex and medulla, respectively, than measured without this inhibitor (Fig. 6). Thus, ouabain-sensitive $\mathrm{H}^{+}, \mathrm{K}^{+}$-ATPase is responsible for about $12 \%$ of ouabain-sensitive " $\mathrm{Na}^{+}, \mathrm{K}^{+}$-ATPase" activity measured by our traditional method. This con-

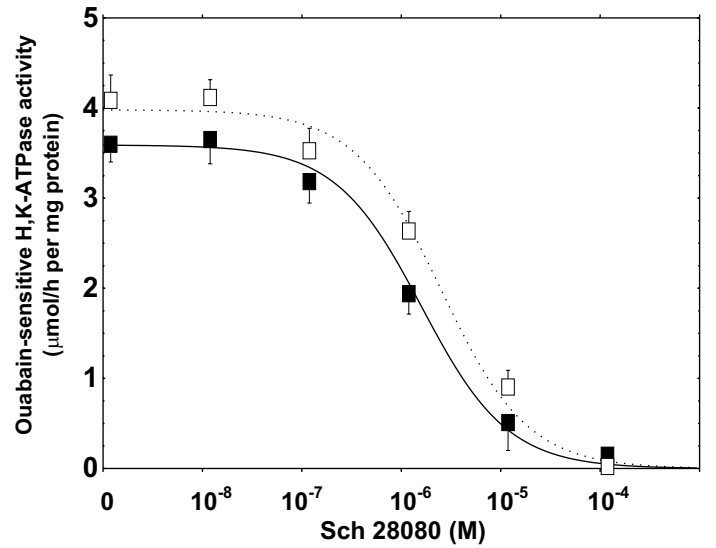

Figure 5. The effect of Sch 28080 on renal ouabain-sensitive $\mathrm{H}^{+}, \mathrm{K}^{+}$-ATPase activity in the renal cortex (black squares and continuous line) and medulla (white squares and broken line).

Vertical axis represents the difference between ATPase activities assayed in the absence and in the presence of $1 \mathrm{mM}$ ouabain, each sample containing 5 $\mathrm{mM} \mathrm{K}^{+}$. Sch 28080 at different concentrations was added to both samples. Points represent mean \pm S.E.M. from 8 experiments and curves are the best fits of means to Eqn. 2 (see Methods).

clusion is based on the assumption that Sch 28080 at this concentration completely inhibits $\mathrm{H}^{+}, \mathrm{K}^{+}$-ATPase. Since Sch 28080 competes

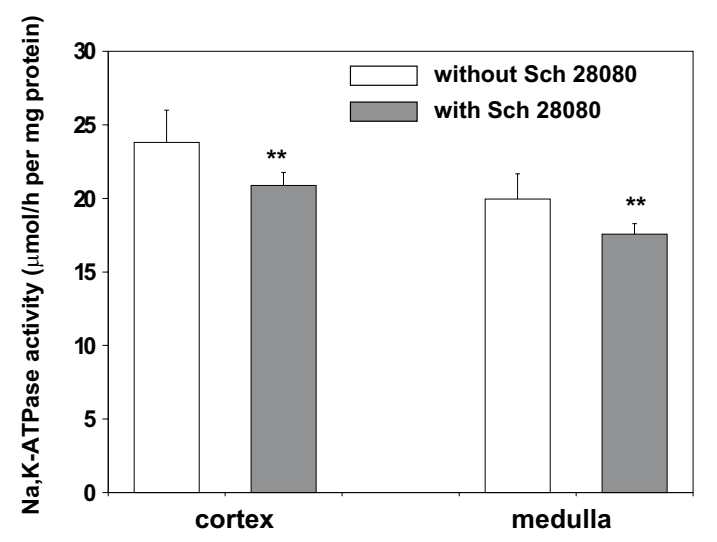

Figure 6. Ouabain-sensitive $\mathrm{Na}^{+}, \mathrm{K}^{+}$-ATPase activity assayed in the absence and in the presence of $0.2 \mathrm{mM}$ Sch 28080 .

The data are differences between samples assayed in the absence and in the presence of $2 \mathrm{mM}$ ouabain. ${ }^{* *} P<0.01$ (compared to the activity assayed without Sch 28080 by paired Student's $t$-test). 
with $\mathrm{K}^{+}$binding site of $\mathrm{H}^{+}, \mathrm{K}^{+}$-ATPase (Beil et al., 1987), it could be suspected that this compound does not completely block the enzyme under our conditions of $\mathrm{Na}^{+}, \mathrm{K}^{+}$-ATPase assay, in which $\mathrm{K}^{+}$concentration $(20 \mathrm{mM})$ is 4 -fold higher than during $\mathrm{H}^{+}, \mathrm{K}^{+}$-ATPase assay. Poor solubility of Sch 28080 did not allow us to check the effect of its higher concentrations and to test the completeness of $\mathrm{H}^{+}, \mathrm{K}^{+}$-ATPase inhibition. Moreover, higher concentrations of Sch 28080 could inhibit other ATPases including $\mathrm{H}^{+}$-ATPase (Sabolic et al., 1994) or even $\mathrm{Na}^{+}, \mathrm{K}^{+}$-ATPase itself (Beil et al., 1987). Assuming that $V_{\max }, K_{\mathrm{m}}$ for potassium and $K_{\mathrm{i}}$ for ouabain of $\mathrm{H}^{+}, \mathrm{K}^{+}$-ATPase determined by us previously are valid also under conditions of the present $\mathrm{Na}^{+}, \mathrm{K}^{+}$-ATPase assay, we calcu-
ATPase" was in fact ouabain-sensitive $\mathrm{H}^{+}, \mathrm{K}^{+}$ATPase.

To verify this conclusion, we performed an additional experiment. We determined the kinetics of $\mathrm{Na}^{+}, \mathrm{K}^{+}$-ATPase inhibition by ouabain in the absence and in the presence of Sch 28080. We have hypothesized that if ouabainsensitive $\mathrm{H}^{+}, \mathrm{K}^{+}$-ATPase operates during the $\mathrm{Na}^{+}, \mathrm{K}^{+}$-ATPase assay, it should be possible to distinguish these two enzymes on the basis of their different kinetic profiles. We took advantage of the fact that rat $\mathrm{Na}^{+}, \mathrm{K}^{+}$- ATPase $\alpha 1$ subunit, which dominates in the kidney, is at least by one order of magnitude less sensitive to ouabain than $\alpha$ subunits of other $\mathrm{X}^{+}, \mathrm{K}^{+}$ATPases. Figure 7 (left) shows medullary $\mathrm{Na}^{+}, \mathrm{K}^{+}$-ATPase activity at different ouabain
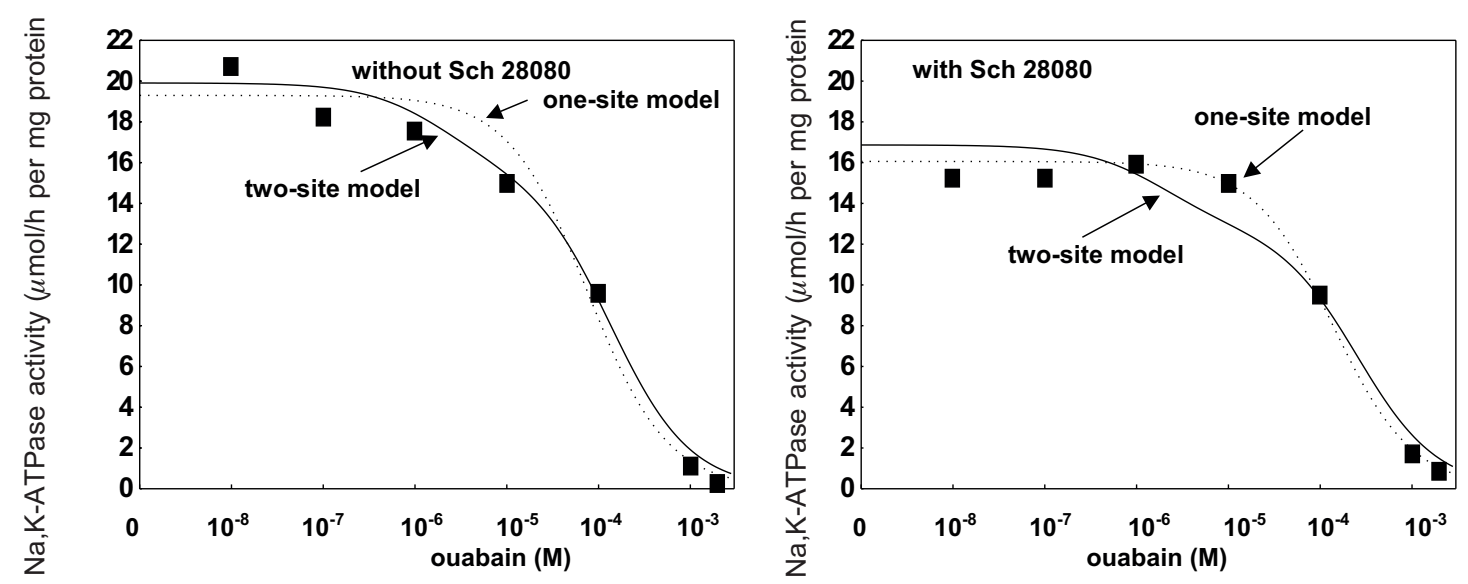

Figure 7. The effect of increasing concentration of ouabain on ouabain-inhibitable ATPase activity in the renal medulla assayed in the presence of $100 \mathrm{mM} \mathrm{NaCl}$ and $20 \mathrm{mM} \mathrm{KCl}$.

Values were calculated as the difference between the activity assayed in the presence of increasing concentrations of ouabain ( $\left.0-2 \times 10^{-3} \mathrm{M}\right)$ and that assayed in the presence of $5 \mathrm{mM}$ ouabain. The experiment was performed in the absence (left) and in the presence (right) of Sch 28080. Points represent means from 5 experiments and curves are best fits to the data by one-site and two-site model, respectively (see Results).

lated that in the presence of $20 \mathrm{mM} \mathrm{K} \mathrm{K}^{+}, 0.2$ $\mathrm{mM}$ Sch 28080 inhibited $\mathrm{H}^{+}, \mathrm{K}^{+}$-ATPase by over $99 \%$ in both parts of the kidney. The absolute amount by which Sch 28080 decreased ouabain-sensitive " $\mathrm{Na}^{+}, \mathrm{K}^{+}$-ATPase" was comparable to previously measured ouabain-sensitive $\mathrm{H}^{+}, \mathrm{K}^{+}$-ATPase activity, indicating that Sch 28080-sensitive moiety of $" \mathrm{Na}^{+}, \mathrm{K}^{+}$. concentrations and two curves: one fitted according to standard one-site model, assuming a homogeneous population of enzyme molecules (see Eqn. 2 in Materials and Methods) and another fitted by two-site model (Shyjan et al., 1990). The latter model assumes that both $\mathrm{Na}^{+}, \mathrm{K}^{+}$-ATPase and $\mathrm{H}^{+}, \mathrm{K}^{+}$-ATPase operate simultaneously, each having its distinct 
$V_{\max }$ and $K_{\mathrm{i}}$ values. The parameters for $\mathrm{Na}^{+}, \mathrm{K}^{+}$-ATPase were allowed to vary whereas those for $\mathrm{H}^{+}, \mathrm{K}^{+}$-ATPase were taken from previous calculations (Fig. 4). In the absence of Sch 28080 the data were better fitted by the two-site $\left(\mathrm{r}^{2}=0.975\right)$ than by the one-site $\left(\mathrm{r}^{2}=\right.$ 0.941) model, whereas in the presence of Sch 28080 (right part of Fig. 7), one site model was more adequate $\left(\mathrm{r}^{2}=0.987\right)$ than the two-site one $\left(\mathrm{r}^{2}=0.95\right)$. In addition, $V_{\max }$ and $K_{\mathrm{i}}$ for $\mathrm{Na}^{+}, \mathrm{K}^{+}$-ATPase in one-site model in the presence Sch $28080(16.6 \mu \mathrm{mol} / \mathrm{h}$ per mg protein and $137 \mu \mathrm{M}$, respectively) were comparable to values obtained from two-site model in the absence of Sch 28080 ( $15.56 \mu \mathrm{mol} / \mathrm{h}$ per mg protein and $138 \mu \mathrm{M})$. The data are consistent with the hypothesis that both ATPases operate in the absence of Sch 28080, whereas only $\mathrm{Na}^{+}, \mathrm{K}^{+}$-ATPase remains active in the presence of this inhibitor. This supports the usefulness of the presented protocol for discriminating these two enzymes.

\section{The effect of leptin on renal $\mathrm{Na}^{+}, \mathrm{K}^{+}$-ATPase and ouabain-sensitive $\mathrm{H}^{+} \mathrm{K}^{+}$-ATPase}

Previously we have reported that leptin, an adipose tissue hormone, decreases $\mathrm{Na}^{+}, \mathrm{K}^{+}$-ATPase activity in the renal medulla (Bełtowski et al., 1999). In that study Sch 28080 was not added, thus, in view of the data presented here, the assay was not strictly specific for $\mathrm{Na}^{+}, \mathrm{K}^{+}$-ATPase. Therefore, we examined the effect of leptin on $\mathrm{Na}^{+}, \mathrm{K}^{+}$-ATPase measured in the presence of Sch 28080, as well as on ouabain-sensitive $\mathrm{H}^{+}, \mathrm{K}^{+}$-ATPase. Leptin (1 mg/kg i.p.) decreased $\mathrm{Na}^{+}, \mathrm{K}^{+}$ATPase activity in the renal medulla at $1 \mathrm{~h}$ after hormone administration from $19.9 \pm 0.7$ to $13.1 \pm 1.0 \mu \mathrm{mol} / \mathrm{h}$ per mg protein $(P<0.001)$ in the absence of Sch 28080, and from $17.6 \pm$ 0.7 to $11.9 \pm 0.9 \mu \mathrm{mol} / \mathrm{h}$ per $\mathrm{mg}$ protein $(P<$ $0.001)$ in its presence. In contrast, leptin had no effect on $\mathrm{Na}^{+}, \mathrm{K}^{+}$-ATPase in the renal cortex. Ouabain-sensitive $\mathrm{H}^{+}, \mathrm{K}^{+}$-ATPase activity was unchanged following leptin administration either in the cortex or in the medulla.
Thus, the adipose tissue hormone decreased renal medullary $\mathrm{Na}^{+}, \mathrm{K}^{+}$-ATPase activity but had no effect on ouabain-sensitive $\mathrm{H}^{+}, \mathrm{K}^{+}$-ATPase.

\section{DISCUSSION}

In this study we describe a reliable method for the determination of ouabain-sensitive $\mathrm{H}^{+}, \mathrm{K}^{+}$-ATPase hydrolytic activity in the isolated microsomal fraction of renal cortex and medulla. The enzyme assayed in our study corresponds most likely to "type II" $\mathrm{H}^{+}, \mathrm{K}^{+}$-ATPase first described by Doucet's group (Younes-Ibrahim et al., 1995; BuffinMeyer et al., 1997) in proximal tubule and thick ascending limb of normokalemic rats, because: 1 ) it is activated by $\mathrm{K}^{+}$in the absence of $\mathrm{Na}^{+}, 2$ ) is sensitive to both ouabain and Sch $28080,3)$ is not active when $\mathrm{K}^{+}$is replaced by $\mathrm{Na}^{+}$. In contrast, "type I" $\mathrm{K}^{+}$-ATPase is insensitive to ouabain whereas "type III" is ouabain-sensitive but appears only in hypokalemic rats and, unlike type II, can be activated by either $\mathrm{K}^{+}$or $\mathrm{Na}^{+}$(Doucet, 1997). Our results indicate that ouabain-sensitive $\mathrm{H}^{+}, \mathrm{K}^{+}$ATPase activity is higher in the renal medulla than in cortex, but in either part of the kidney it is much lower than that of $\mathrm{Na}^{+}, \mathrm{K}^{+}$-ATPase. We failed to develop an effective method for the ouabain-resistant (type I) $\mathrm{H}^{+}, \mathrm{K}^{+}$-ATPase assay. We suggest that the activity of this enzyme, expressed normally only in the intercalated cells of the collecting duct (LarocheJoubert et al., 2000), is too low to be detected in whole-kidney homogenates. Further studies on $\mathrm{K}^{+}$-depleted rats are required to clarify whether it would be possible to determine "type III" $\mathrm{H}^{+}, \mathrm{K}^{+}$-ATPase by a method similar to the presented here.

One could suggest that ouabain-sensitive $\mathrm{H}^{+}, \mathrm{K}^{+}$-ATPase assayed in this study is in fact $\mathrm{Na}^{+}, \mathrm{K}^{+}$-ATPase activated by tracer amounts of sodium present in the incubation mixture, originating from homogenized tissue or reagent contamination. Several lines of evi- 
dence indicate that this is not the case. First, it could be calculated from $\mathrm{Na}^{+}$activation curves established by us for cortical and medullary $\mathrm{Na}^{+}, \mathrm{K}^{+}$-ATPase (unpublished observation) that the activation of sodium pump to the level observed in this study would require $\mathrm{Na}^{+}$concentration of about $15 \mathrm{mM}$, which was absolutely unlikely to occur in our experiment. Second, $\mathrm{H}^{+}, \mathrm{K}^{+}$-ATPase was completely inhibited by Sch 28080 which has no effect on $\mathrm{Na}^{+}, \mathrm{K}^{+}$-ATPase (Codina et al., 2000). Third, if sodium contamination activated $\mathrm{Na}^{+}, \mathrm{K}^{+}$-ATPase in $\mathrm{K}^{+}$-containing medium, the same should be observed when $\mathrm{K}^{+}$was replaced by $\mathrm{Na}^{+}$due to possible potassium contamination. The latter is in fact even more likely, because $K_{\mathrm{m}}$ of $\mathrm{Na}^{+}, \mathrm{K}^{+}$-ATPase for $\mathrm{K}^{+}$is much lower than for $\mathrm{Na}^{+}$(Shyjan et al., 1990), so lower amounts of contaminating potassium would be needed to cause comparable $\mathrm{Na}^{+}, \mathrm{K}^{+}$-ATPase stimulation. However, no ouabain-sensitive activity was observed in samples to which $\mathrm{Na}^{+}$but not $\mathrm{K}^{+}$was added. Fourth, leptin decreased medullary $\mathrm{Na}^{+}, \mathrm{K}^{+}$-ATPase activity but had no effect on ouabain-sensitive $\mathrm{H}^{+}, \mathrm{K}^{+}$-ATPase. Finally, no ouabain-sensitive $\mathrm{H}^{+}, \mathrm{K}^{+}$-ATPase was detected in brain or heart, in which $\mathrm{Na}^{+}, \mathrm{K}^{+}$-ATPase is abundantly expressed. These data strongly confirm the specificity of the described $\mathrm{H}^{+}, \mathrm{K}^{+}$-ATPase assay.

Most studies concerning renal ATPases are now performed on isolated tubular segments or intact cultured tubular cells. These methods have, however, some limitations and therefore methods measuring enzyme activity in broken cell preparations, like the method described in the present study, are also popular (Chiou \& Vesely, 1995; Khundimiri \& Lederer, 2002). First, isolation of tubules is time-consuming, consequently, if one wants to investigate the effect of mediators (which is usually short lasting), it is not possible to administer them in vivo, before tubule isolation. In such studies, the examined mediators are rather applied in vitro, during or just before the ATPase assay, after the tubules have been isolated from their natural environment, such as osmolality and oxygen tension changing along the nephron. Such conditions can affect signal transduction mechanisms involved in the regulation of ATPases (Kiroytcheva et al., 1999). The method described here allows to study the effect of hormones administered in vivo before the isolation of microsomal fraction (Bełtowski et al., 1998a; 1998b). Second, $\mathrm{H}^{+}, \mathrm{K}^{+}$-ATPase activity in intact cells is often measured indirectly, as rubidium/potassium reabsorption, luminal acidification or bicarbonate transport. Therefore, other transporting mechanisms such as $\mathrm{H}^{+} / \mathrm{K}^{+}$antiport can distort the results (Attmane-Elakeb et al., 1997). Third, proteases often used during tubule isolation can degrade $\mathrm{H}^{+}, \mathrm{K}^{+}$-ATPase, falsely decreasing its expression in ex vivo studies (Fejes-Tóth \& Fejes-Tóth, 2001). Most importantly, however, apart from its specific effect on $\mathrm{H}^{+}, \mathrm{K}^{+}$-ATPase, Sch 28080 can nonspecifically inhibit $\mathrm{Na}^{+}, \mathrm{K}^{+}$-ATPase in whole cells by decreasing intracellular ATP concentration, in contrast, Sch 28080 has no effect on $\mathrm{Na}^{+}, \mathrm{K}^{+}$-ATPase in broken cell preparations (Codina et al., 2000).

Certainly, there are also potential disadvantages of the method described here. First, both renal cortex and medulla are heterogeneous, therefore it is not possible to conclude in which nephron segment the observed effect really occur. It seems that this is a lesser problem for ouabain-sensitive $\mathrm{H}^{+}, \mathrm{K}^{+}$-ATPase than for $\mathrm{Na}^{+}, \mathrm{K}^{+}$-ATPase, since the former is distributed in a more restricted manner. The situation will become more complex in pathological conditions, such as potassium depletion (Buffin-Meyer et al., 1997) or sodium depletion (Sangan et al., 1997; Silver et al., 1998), when type III $\mathrm{H}^{+}, \mathrm{K}^{+}$-ATPase appears in the collecting duct. This isoform is also ouabainsensitive, however, it is likely that it will be possible to distinguish it from type II by its sodium sensitivity.

This study also demonstrates that about $12 \%$ of " $\mathrm{Na}^{+}, \mathrm{K}^{+}$-ATPase" assayed as ouabain-sensitive ATP hydrolyzing activity in the presence 
of $\mathrm{Na}^{+}$and $\mathrm{K}^{+}$is in fact accounted for by ouabain-sensitive $\mathrm{H}^{+}, \mathrm{K}^{+}$-ATPase. Although this will not affect conclusions based on $30-40 \%$ changes in $\mathrm{Na}^{+}, \mathrm{K}^{+}$-ATPase activity, like those observed in our previous studies (Bełtowski et al., 1998a; 1998b), more moderate effects could in fact result from changes in $\mathrm{H}^{+}, \mathrm{K}^{+}$-ATPase rather than $\mathrm{Na}^{+}, \mathrm{K}^{+}$-ATPase activity. Therefore, we recommend using Sch 28080 in future studies concerning $\mathrm{Na}^{+}, \mathrm{K}^{+}$ATPase to improve the specificity of the assay.

The regulation of renal $\mathrm{Na}^{+}, \mathrm{K}^{+}$-ATPase has been extensively studied (Feraille \& Doucet, 2001). In contrast, the mechanisms regulating $\mathrm{H}^{+}, \mathrm{K}^{+}$-ATPase are largely unknown. Its activity is affected by hypokalemia (BuffinMeyer et al., 1997), acid-base status (Wesson, 1998), sodium depletion (Sangan et al., 1997; Silver et al., 1998) and ischemia-reperfusion injury (Wang et al., 1997), but neither the mediators nor the intracellular signal transduction pathway involved have been recognized. The method described here opens the possibility to study $\mathrm{H}^{+}, \mathrm{K}^{+}$-ATPase regulation both in physiological and pathological conditions.

The authors wish to thank Schering Plough Research Institute (Kenilworth, NJ, U.S.A.) for the free sample of Sch 28080, without which this study would not have been possible.

\section{R E F E R E N C E S}

Attmane-Elakeb A, Boulanger H, Vernimmen C, Bichara M. (1997) Apical location and inhibition by arginine vasopressin of $\mathrm{K}^{+} / \mathrm{H}^{+}$ antiport of the medullary thick ascending limb of rat kidney. J Biol Chem.; 272: 25668-77.

Beil W, Staar U, Sewing KF. (1987) SCH 28080 is a more selective inhibitor than SCH 32651 at the $\mathrm{K}^{+}$site of gastric $\mathrm{K}^{+} / \mathrm{H}^{+}$-ATPase. Eur $J$ Pharmacol.; 139: 349-52.
Bełtowski J, Górny D, Marciniak A. (1998a) The mechanism of $\mathrm{Na}^{+}, \mathrm{K}^{+}$-ATPase inhibition by atrial natriuretic factor in rat renal medulla. J Physiol Pharmacol.; 49: 271-83.

Bełtowski J, Górny D, Marciniak A. (1998b) Biphasic effect of protein kinase $\mathrm{C}$ on rat renal cortical $\mathrm{Na}^{+}, \mathrm{K}^{+}$-ATPase. J Physiol Pharmacol.; 49: 625-37.

Bełtowski J, Wójcicka G, Górny D, Marciniak A. (1999) Human leptin administered intraperitoneally decreases renal medullary but not cortical $\mathrm{Na}^{+}, \mathrm{K}+$-ATPase in the rat. Physiol Res.; 48 Suppl 1: S56.

Buffin-Meyer B, Younes-Ibrahim M, Barlet-Bas C, Cheval L, Marsy S, Doucet A. (1997) K depletion modifies the properties of Sch-28080-sensitive K-ATPase in rat collecting duct. Am J Physiol.; 272, F124-31.

Caruso-Neves C, Rangel LB, Vives D, Vieyra A, Coka-Guevara S, Lopes AG. (2000)

Ouabain-insensitive $\mathrm{Na}^{+}$-ATPase activity is an effector protein for cAMP regulation in basolateral membranes of the proximal tubule. Biochim Biophys Acta.; 1468: 107-14.

Chiou S, Vesely DL. (1995) Kaliuretic peptide: the most potent inhibitor of $\mathrm{Na}^{+}-\mathrm{K}^{+}$ATPase of the atrial natriuretic peptides. Endocrinology.; 136: 2033-9.

Codina J, Cardwell J, Gitomer JJ, Cui Y, Kone BC, Dubose Jr TD. (2000) Sch-28080 depletes intracellular ATP selectively in mIMCD-3 cells. Am J Physiol.; 279: C1319-26.

Doucet A, Marsy S. (1987) Characterization of K-ATPase activity in distal nephron: stimulation by potassium depletion. Am J Physiol.; 253: F418-23.

Doucet A. (1997) $\mathrm{H}^{+}, \mathrm{K}^{+}$-ATPase in the kidney: localization and function in the nephron. Exp Nephrol.; 5: 271-6.

Fejes-Tóth G, Fejes-Tóth AN. (2001) Immunohistochemical localization of colonic H-K-ATPase to the apical membrane of connecting tubule cells. Am J Physiol.; 281: F318-25.

Feraille E, Doucet A. (2001) Sodium-potassium-adenosinetriphosphatase-dependent so- 
dium transport in the kidney: hormonal control. Physiol Rev.; 81: 345-418.

Garg LC, Narang N. (1988) Ouabain-insensitive K-adenosine triphosphatase in distal nephron segments of the rabbit. $J$ Clin Invest.; 81: 1204-8.

Giebisch G, Wang W. (1996) Potassium transport: from clearance to channels and pumps. Kidney Int.; 49: 1624-31.

Giebisch G. (1998) Renal potassium transport: mechanisms and regulation. Am J Physiol.; 274: F817-33.

Hurst RO. (1964) The determination of nucleotide phosphorus with a stannous chloridehydrazine sulphate reagent. Can J Biochem.; 42: 287-92.

Jörgensen PL. (1974) Purification and characterisation of $\left(\mathrm{Na}^{+}+\mathrm{K}^{+}\right)$-ATPase. III. Purification from outer medulla of mammalian kidney after selective removal of membrane components with sodium dodecylsulphate. Biochim Biophys Acta.; 356: 36-52.

Khundimiri SJ, Lederer, A. (2002) PTH and DA regulate Na-K ATPase through divergent pathways. Am J Physiol.; 282: F512-22.

Kiroytcheva M, Cheval L, Carranza ML, Martin PY, Favre H, Doucet A, Feraille E. (1999) Effect of cAMP on the activity and the phosphorylation of $\mathrm{Na}^{+}, \mathrm{K}^{+}$-ATPase in rat thick ascending limb of Henle. Kidney Int.; 55: $1819-31$.

Laroche-Joubert N, Marsy S, Doucet A. (2000) Cellular origin and hormonal regulation of $\mathrm{K}^{+}$-ATPase activities sensitive to Sch-28080 in rat collecting duct. Am J Physiol.; 279: F1053-59.

Lowry OH, Rosebrough NI, Farr AL, Randall RJ. (1951) Protein measurement with the Folin phenol reagent. J Biol Chem.; 193: 265-75.

Muto S. (2001) Potassium transport in the mammalian collecting duct. Physiol Rev.; 81: 85-116.
Rabinowitz L. (1996) Aldosterone and potassium homeostasis. Kidney Int.; 49: 1738-42.

Sabolic I, Brown D, Verbavatz JM, Kleinman J. (1994) $\mathrm{H}^{+}$-ATPases of renal cortical and medullary endosomes are differentially sensitive to Sch-28080 and omeprazole. Am J Physiol.; 266: F868-77.

Sangan P, Rajendran VM, Mann AS, Kashgarian M, Binder HJ. (1997) Regulation of colonic H-K-ATPase in large intestine and kidney by dietary $\mathrm{Na}$ depletion and dietary $\mathrm{K}$ depletion. Am J Physiol.; 272: C685-96.

Shyjan AW, Cena V, Klein DC, Levenson R. (1990) Differential expression and enzymatic properties of the $\mathrm{Na}^{+}, \mathrm{K}^{+}$-ATPase $\alpha 3$ isoenzyme in rat pineal glands. Proc Natl Acad Sci U S A.; 87: 1178-82.

Silver RB, Choe H, Frindt G. (1998) Low-NaCl diet increases H-K-ATPase in intercalated cells from rat cortical collecting duct. Am J Physiol.; 275: F94-F102.

Silver RB, Soleimani M. (1999) $\mathrm{H}^{+}-\mathrm{K}^{+}$-ATPases: regulation and role in pathophysiological states. Am J Physiol.; 276: F799-F811.

Sweeney G, Nu W, Kanani R, Klip A. (2000) Regulation of the Na,K-pump by leptin in 3T3-L1 fibroblasts. Endocrinology.; 141: 1277-80.

Wang Z, Rabb H, Craig T, Burnham C, Shull GE, Solemani M. (1997) Ischemic-reperfusion injury in the kidney: overexpression of colonic $\mathrm{H}^{+}, \mathrm{K}^{+}$-ATPase and suppression of NHE-3. Kidney Int.; 51: 1106-15.

Wesson DE. (1998) Na/H exchange and H-K ATPase increase tubule acidification in chronic alkalosis. Kidney Int.; 53: 945-51.

Wingo CS, Smolka AJ. (1995) Function and structure of H-K-ATPase in the kidney. Am J Physiol.; 269: F1-16.

Younes-Ibrahim M, Barlet-Bas C, Buffin-Meyer B, Cheval L, Rajerison R, Doucet A. (1995) Ouabain-sensitive and -insensitive K-ATPases in rat nephron: effect of $\mathrm{K}$ depletion. Am $J$ Physiol.; 268: F1141-7. 